\title{
Aplikasi Pemetaan Kantor Dinas Di Kabupaten Bangkalan-Madura Berbasis Android
}

\author{
1) Devie Rosa Anamisa, ${ }^{2)}$ Aeri Rachmad \\ Universitas Trunojoyo Madura, Jl. Raya Telang PO BOX 2 Kamal, Madura \\ E-mail: devros_gress@yahoo.com ${ }^{1)}$,aery_r@yahoo.com ${ }^{2)}$
}

\begin{abstract}
ABSTRAKS
Saat ini perkembangan teknologi sangat pesat, salah satunya pada aplikasi pencarian lokasi, menyebabkan banyak uji pemetaan semakin mudah dilakukan. Salah satu pencarian lokasi yang biasa dilakukan adalah pencarian lokasi dengan Google-Map. Namun keterbatasan Google-Map hanya melakukan pencarian lokasi kantor-kantor dinas wilayah madura khususnya Bangkalan. Untuk menyampaikan informasi lokasi tersebut dirasa kurang praktis karena tidak bersifat 'mobile', sementara mobilitas manusia semakin tinggi. Android merupakan sistem operasi terbuka yang digunakan untuk smart phone yang saat ini sedang sangat diminati oleh masyarakat. Pada penelitian ini menghasilkan suatu aplikasi yang mengimplementasikan pemetaan infrastruktur kantor-kantor dinas Kabupaten Bangkalan-Madura untuk mempermudah dalam proses pencarian lokasi dan juga informasi layanan di tiap kantor dinas wilayah Madura khususnya Bangkalan. Hasil penelitian ini diharapkan menghasilkan analisa yang akan digunakan sebagai pertimbangan dalam pemetaan infrastruktur kantor baik Dinas Capil, Dinas Kesehatan, Dinas Pendidikan, Dinas Koperasi, dan Dinas Pertanian di Kabupaten Bangkalan dengan sistem layanan berbasis lokasi (LBS) berbasis android.
\end{abstract}

Kata Kunci: Pemetaan, Kantor Dinas Bangkalan, Android

\section{PENDAHULUAN}

Data merupakan suatu aspek penting dalam menunjang suatu instansi atau kantor dinas. Seringkali data yang dimiliki hanya digunakan sebagai inventaris tanpa adanya pemanfaatan terhadap keberadaan data tersebut. Kantor dinas tentunya sangat diperlukan oleh masyarakat dalam memberi layanan untuk mencetak akta kematian, akta kelahiran, membuat surat pengajuan bantuan dana untuk membuka usaha, dan lain sebagainya. Namun kondisi seperti ini membutuhkan layanan yang sesuai untuk menemukan lokasi kantor dinas dan prosedur sebelum membuat surat permohonan maka diperlukan pengolahan data lebih lanjut sebagai solusi yang tepat dalam menangani pelayanan di kantor-kantor dinas wilayah Madura khususnya Bangkalan. Data yang digunakan sebagai data yang diolah adalah data layanan berbasis lokasi (LBS), dimana suatu layanan informasi yang dapat diakses menggunakan piranti mobile melalui jaringan internet dan telepon seluler menggunakan sistem GPS. Faktor yang mempengaruhi diantaranya lokasi kantor dinas, jarak ke lokasi kelurahan terdekat atau kantor kecamatan terdekat, dan faktor-faktor lain yang menentukan.

Oleh karena itu pencarian lokasi kantor dinas beserta informasi layanan yang ada, maka akan sulit bagi pihak kantor dinas untuk menganalisa apakah pemetaan infrastruktur di tiap kantor dinas kota Bangkalan sudah tepat guna dan lebih efisien. Untuk mengatasi hal tersebut maka diperlukan aplikasi
webGIS untuk mendapatkan informasi sebagai bahan pertimbangan. Model data yang digunakan dengan menentukan daerah yang ada dalam peta dengan symbol dan indeks warna sehingga terlihat jelas daerah yang dituju kemudian digital peta pada Quantum GIS terdapat tiga jenis layer aitu polygon, point dan garis dan juga ditambahkan atribut sesuai kebutuhan masing-masing objek dan tersimpan dalam tabel pada PostgreSQL sehingga pada aplikasi webGIS tersebut akan melakukan pencarian dan memberikan informasi nama tempat ibadah, alamat, nomor telp dan kapasitas daya ampung tempat ibadah tersebut (Sari Rahmi Nursuci, 2011). Dan menggunakan teknologi esensial dalam menyimpan, memanipulasi, menganalisis dan menampilkan kembali kondisi-kondisi dengan data atribut dan spasial sehingga terrepresentasikan secara real world diatas komputer sebagaimana lembaran peta diatas kertas (Arfiani, Ika. 2012). ArcView merupakan perangkat lunak GIS yang sangat popular dan paling banyak digunakan untuk mengelola data spasial sehingga data tersebut dianalisis dan dibuat peta serta laporan yang berkaitan dengan data spasial bereferensi geografis sehingga dihasilkan project, view, tabel, chart, layout dan script (Ria Awaliya, 2013).

Oleh karena itu dalam penelitian ini memiliki tujuan dapat membangun suatu sistem yang mempermudah dalam proses pencarian lokasi dan juga informasi layanan di tiap kantor dinas wilayah Madura khususnya Bangkalan. Pada penelitian ini, sistem yang 
akan dibangun adalah pemetaan infrastruktur kantorkantor dinas Kota Bangkalan dengan sistem layanan berbasis lokasi (LBS) berbasis android.

\section{Tinjauan Pustaka}

Dinas daerah kabupaten atau kota merupakan unsur pelaksana pemerintah kabupaten atau kota. Dinas kabupaten atau kota mempunyai tugas melaksanakan kewenangan desentralisasi. Pada dinas daerah kabupaten/kota dapat dibentuk unit pelaksana teknis Dinas daerah (UPTD) kabupaten/kota untuk melaksanakan sebagian tugas Dinas yang mempunyai wilayah kerja satu atau beberapa kecmatan. Dan setiap daerah kabupaten/kota memiliki karakteristik yang berbeda-beda, sehingga penamaan dinas tersebut dapat berbeda pula di tiap-tiap kabupaten/kota. Pada penelitian ini terdapat lima kantor dinas di Bangkalan, diantaranya Dinas Kependudukan Dan Pencatatan Sipil memiliki beberapa jenis layanan diantaranya penerbitan/pembuatan Kartu Keluarga (KK), penerbitan Surat Keterangan Pindah WNI, penerbitan/pembuatan Kartu Tanda Penduduk (KTP),pembuatan akta kematian, dan juga pembuatan akta kelahiran. Pada dinas kesehatan juga memiliki layanan khusus, diantaranya perijinan toko obat, Perawat SIK \& SIPP, Bidan (SKB dan SIPB) dan perijinan Dokter. Sedangkan dinas pendidikan memiliki beberapa layanan, diantaranya pengajuan Surat Keterangan Pengganti Ijazah Yang Rusak/Hilang, pengajuan Surat Ijin Pendirian Sekolah Swasta, pengajuan ijin penambahan program studi/keahlian SMK, pengajuan Surat Ijin Perpanjangan Sekolah Swasta, pengajuan Surat Ijin Pendirian Kelompok Bermain (KB) Dan Tempat Penitipan Anak (TPA) dan pengajuan Melanjutkan Sekolah Keluar Kabupaten. Pada dinas koperasi dan usaha mikro kecil menengah memberikan fasilitas diantaranya pengembangan Hasil Produksi Bagi Usaha Kecil Menengah, peningkatan Kemitraan Usaha Bagi Umkm dan penyelenggaraan pelatihan kewirausahaan. Dinas yang terakhir adalah Dinas Pertanian dan Peternakan, dimana memiliki layanan, diantaranya informasi mengenai peningkatan produksi tanaman dan cara membudidayakan tanaman (http://www.dinaswikipedia.org, 01 agustus 2014).

\subsection{Dasar Pemetaan Lokasi dengan GPS Berbasis Android}

Pemetaan lokasi merupakan system informasi geografi yang sistem untuk pengelolaan, penyimpanan, pemrosesan, analisis dan pendayagunaan data yang terkait yang terkait dengan permukaan bumiatau disebut dengan sistem informasi geografis. Pemetaannya terbagi dalam data input merupakan subsistem untuk mengumpulkan dan mempersiapkan data spasial dan atribut dari berbagai sumber. Subsistem ini bertanggung jawab dalam mengkonversi atau mentrasformasikan format format data aslinya kedalam format yang dapat digunakan oleh SIG, data ouput yang menampilkan atau menghasilkan keluaran seluruh atau sebagian basisdata baik dalam bentuk softcopy maupun bentuk hardcopy seperti table, grafik, peta dan lain - lain, data manajemen untuk mengorganisasikan baik data spasial maupun atribut kedalam sebuah basisdata sedemikian rupa sehingga mudah dipanggil, di update, dan di edit, dan juga data manipulation untuk menentukan informasi - informasi, analysis, manipulasi dan pemodelan data untuk menghasilkan informasi yang diharapkan (Eddy Prahasta, 2009).

Sedangkan GPS adalah sistem radio navigasi dan penentuan posisi dengan menggunakan satelit yang dimiliki dan dikelola oleh Departemen Pertahanan Keamanan Amerika Serikat. Sistem ini didesain untuk memberikan posisi dan kecepatan tiga dimensi dan informasi mengenai waktu secara kontinu. Sistem GPS, yang nama aslinya adalah NAVSTAR GPS (Navigation Satellite Timing and Ranging Global Positioning System) mempunyai tiga segmen yaitu: satelit/ruang, pengontrol, dan pengguna. Satelit GPS yang mengorbit bumi, dengan orbit dan kedudukan yang tetap (koordinatnya pasti), seluruhnya berjumlah 24 buah dimana 21 buah aktip bekerja dan 3 buah sisanya adalah cadangan. Satelit bertugas untuk menerima dan menyimpan data yang ditransmisikan oleh stasiun - stasiun pengontrol, menyimpan dan menjaga informasi waktu berketelitian tinggi (ditentukan dengan jam atomic di satelit), dan memancarkan sinyal dan informasi secara kontinyu ke pesawat penerima (receiver) dari pengguna. Pengontrol bertugas untuk mengendalikan dan mengontrol satelit dari bumi baik untuk mengecek kesehatan satelit, penentuan dan prediksi orbit dan waktu, sinkronisasi waktu antar satelit, dan mengirim data ke satelit. Sedangkan pengguna bertugas menerima data dari satelit dan memprosesnya untuk menentukan posisi (posisi tiga dimensi yaitu koordinat dibumi plus ketinggian), arah, jarak dan waktu yang diperlukan oleh pengguna. Ada dua macam tipe penerima yaitu tipe NAVIGASI dan tipe GEODETIC (Sanjaya, I,dkk.2012).

Pada dasarnya penentuan posisi dengan GPS adalah pengukuran jarak secara bersama - sama ke beberapa satelit (yang koordinatnya telah diketahui) sekaligus. Untuk menentukan koordinat suatu titik dibumi, receiver setidaknya membutuhkan 4 satelit yang dapat ditangkap sinyalnya dengan baik. Secara default posisi atau koordinat yang diperoleh bereferensi ke global datum yaitu world geodetic system 1984 atau disingkat WGS'84. Secara garis besar penentuan posisi dengan GPS ini dibagi menjadi dua metode yaitu metode absolute dan metode relatif. Metode absolute atau juga dikenal sebagai point positioning, menentukan posisi hanya berdasarkan pada 1 pesawat penerima saja. Ketelitian posisi dalam beberapa meter (tidak berketelitian tinggi) dan umumnya hanya diperuntukkan bagi keperluan NAVIGASI. Sedangkan metode relatif atau sering disebut differential positioning, menentukan posisi dengan menggunakan lebih dari receiver. Satu GPS dipasang pada lokasi tertentu dimuka bumi dan secara terus menerus menerima sinyal dari satelit dalam jangka waktu tertentu dijadikan sebagai referensi bagi yang lainnya. Metode ini menghasilkan posisi 
berketelitian tinggi (umumnya kurang dari 1 meter) dan diaplikasikan untuk keperluan survey GEODESI ataupun pemetaan yang memerlukan ketelitian tinggi.

Pemetaan lokasi menggunakan android adalah suatu aplikasi yang menggunakan sistem operasi untuk telepon seluler yang berbasis Linux. Android menyediakan platform terbuka bagi para pengembang untuk menciptakan aplikasi mereka sendiri untuk digunakan oleh bermacam piranti bergerak. Android bukan sekedar hanya untuk mobile saja, android merupakan sebuah system operasi yang dikemas sedemikian rupa sehingga dapat digunakan untuk berbagai layer, diantaranya application, dimana android akan menggabungkan dengan serangkaian aplikasi inti termasuk klien email, program SMS, kalender, peta, browser, kontak, dan lain - lain, application Framework adalah android memliki fitur pengembangan framework sehingga para pengguna dapat membuat sendiri apikasi di android, libraries merupakan android termasuk satu set pustaka $\mathrm{C} / \mathrm{C}++$ yang digunakan oleh berbagai komponen sistem Android. Selain itu juga terdapat layer android runtime, dimana android termasuk satu set perpustakaan inti yang menyediakan sebagian besar fungsi yang tersedia di perpustakaan inti dari bahasa pemrograman Java. Layer yang terakhir adalah Linux Kernel, dimana android bergantung pada Linux versi 2.6 untuk layanan sistem inti seperti keamanan, manajemen memori, manajemen proses, network stack, dan model pengemudi. Kernel juga bertindak sebagai lapisan abstraksi antara hardware dan seluruh software stack.

\subsection{Layanan Berbasis Lokasi (LBS)}

System layanan berbasis lokasi, atau lebih dikenal dengan Location-Based Service (LBS), yaitu suatu layanan informasi yang dapat diakses menggunakan piranti mobile melalui jaringat internet dan telepon seluler menggunakan sistem GPS dan bertujuan untuk memberikan layanan. Poin pentingnya adalah ketika posisi target, dimana sebuah target bisa jadi adalah pengguna LBS itu sendiri atau entitas lain yang tergabung dalam suatu layanan. Ada 2 macam tipe layanan yang bisa digunakan dalam LBS untuk memperoleh posisi pengguna, diantaranya menggunakan sel jaringan, dengan cara ini layanan LBS medeteksi posisi objek dengan mengunakan posisi sel jaringan dari objek tersebut dan mengguakan GPS atau aGPS, dengan cara ini layanan LBS medeteksi posisi objek dengan mengunakan posisi GPS atau GPS dari objek tersebut (Tawang, N., 2012). Posisi yang diperoleh oleh layanan ini berupa titik kordinat latitude dan longitude. Latitude adalah representasi dari arah Utara-Selatan sedangkan Longitude adalah representasi dari arah Timur-Barat. Berdasarkan jenis layanannya LBS memiliki 2 jenis yag berbeda, diantaranya reactive LBS, merupakan layanan LBS yang hanya akan aktif jika ada aksi yang dilakukan oleh pengguna. Artinya layanan ini akan memberikan informasi kepada pengguna jika penguna meminta informasi tersebut dan proactive LBS, merupakan layanan LBS yang selalu aktif. Artinya
Layanan ini akan terus memberikan informasi kepada pengguna walaupun tidak ada permintaan dari pngguna.

\section{Metodologi \\ 3.1. Analisis dan Perancangan sistem}

Perencanaan pembuatan sistem untuk pemetaan infrastruktur ini digambarkan secara umum pada Gambar 1.

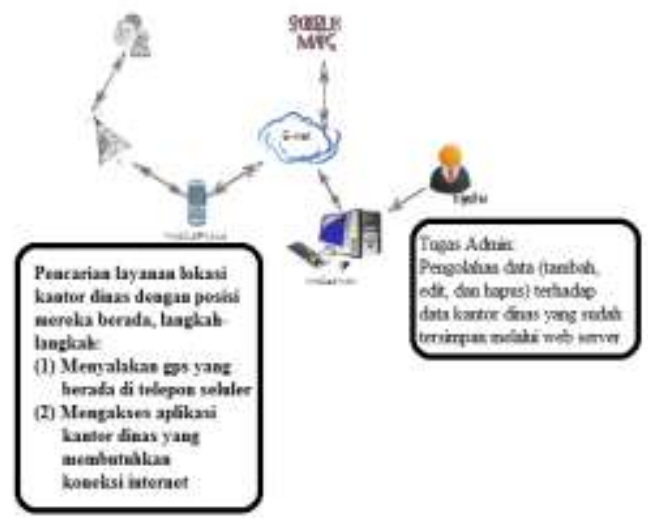

Gambar 1. Perancangan Sistem

Pada tahap ini admin merupakan petugas dari setiap dinas maupun petugas dari setiap kelurahan di Kabupaten Bangkalan yang bertugas sebagai manajemen data baik melakukan aksi update, delete, dan insert dengan mengakses google maps. Sedangkan pengguna merupakan warga masyarakat yang dapat melakukan pencarian lokasi dengan menyalakan GPS pada handphone maka pada peta akan muncul tanda latitude dan longitude sesuai koordinat letak kantor dinas yang dipilih dan secara otomatis akan juga melakukan pencarian layanan yang ada di dinas tersebut.

\section{Hasil Dan Pembahasan}

Hasil dari penelitian ini dapat dilakukan analisis dalam melakukan pemetaan infrastruktur di tiap kantor dinas di Kabupaten Bangkalan dan mengevaluasi setiap layanan yang ada dikantor dinas tersebut beserta prosedur dari layanan tersebut, dapat dilihat pada Gambar 2. Bangkalan Dinas capil dan kependudukan yang melaksanakan pemberian nomor induk (NIK), pendaftaran kartu keluarga (KK), Penerbitan akta dan pencatatan mutasi penduduk, alur/prosedur pemohon diawali dari lokasi pemohon menuju kantor desa/kelurahan, kantor kecamatan, kantor dinas terkait untuk verifikasi berkas pemohon dan penerbitan dokumen. Dinas pendidikan yang melaksanakan pengajuan dana BOOS bagi siswa yang kurang mampu, alur atau prosedurnya diawali dengan pemohon ke kantor kelurahan terdekat, kantor kecamatan kemudian ke kantor dinas pendidikan. Sedangkan dinas Kesehatan yang melaksanakan pendaftaran surat pelayanan miskin, alur atau prosedurnya maka calon pesrta mengajukan SKTM ke kantor desa/kelurahan kantor kecamatan untuk 
dilegalisir kantor dinas kesehatan untuk dibuatkan surat pernyataan miskin.

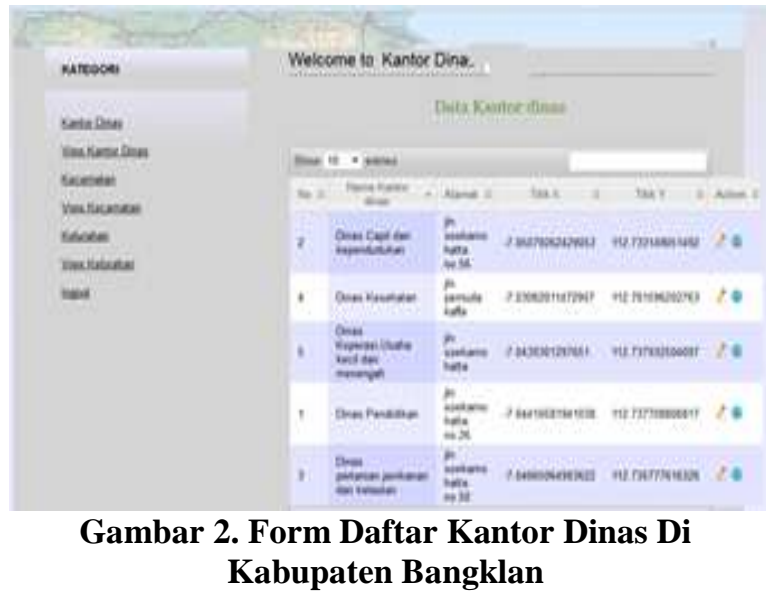

Untuk dinas pertanian yang melaksanakan perlindungan tanaman, alur atau prosedur yaitu langsung ke kantor dinas terkait. Sedangkan dinas koperasi yang melaksanakan pengajuan bantuan dana membuat usaha, alur atau prosedur langsung menuju kantor dinas terkait untuk dibuatkan surat bantuan pemberian dana dapat dilihat pada Gambar 3. Dalam mencari layanan lokasi kantor dinas maka akan tampil peta beserta marker dari layanan lokasi kantor dinas dengan mengaktifkan GPS pada ponsel terlebih dahulu. Marker ini merupakan letak layanan lokasi desa/kelurahan dimana posisi pengguna berada sebelum menuju layanan lokasi kantor kecamatan terkait yang didapatkan dari database server.

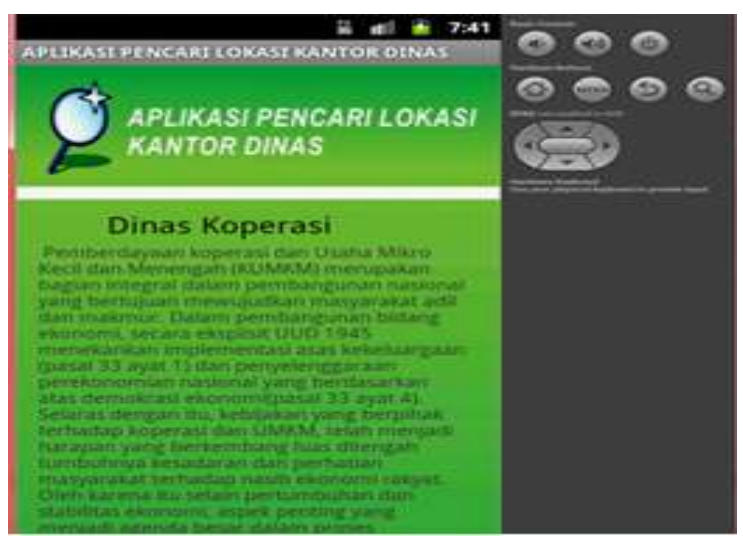

Gambar 3. Form Informasi Layanan Kantor Dinas Koperasi

Pada marker yang tampil pada peta kelurahan memiliki informasi yaitu nama kecamatan, alamat dan jarak dari lokasi pengguna menuju kelurahan atau desa yang dipilih seperti pada Gambar 4. Dengan adanya informasi ini pengguna bisa menemukan tempat yang akan dituju dengan waktu yang relative singkat dengan biaya minimal.

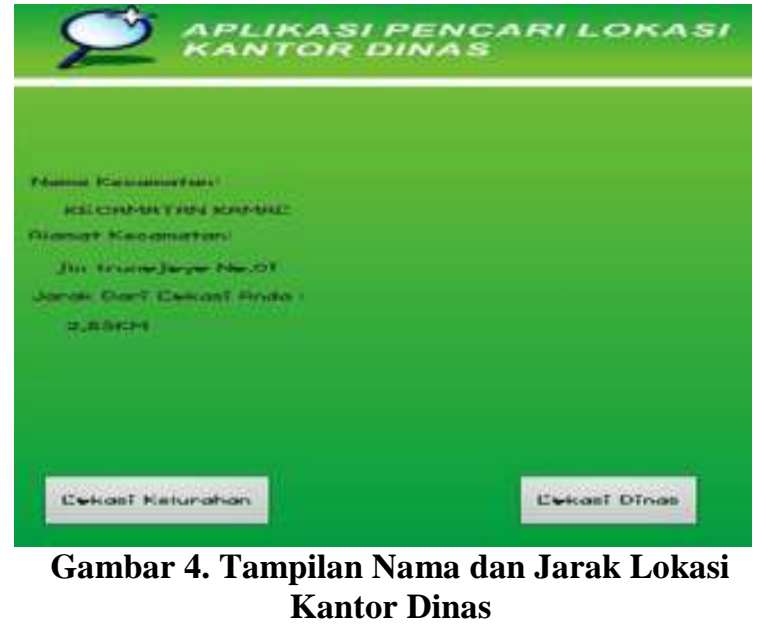

Sedangkan tampilan lokasi kantor dinas dapat dilihat pada Gambar 5. Pada gambar tersebut terlihat detail posisi dari dinas Cacatan Sipil yang terlrtak tepat pada jalan Soekarno - hatta di bangkalan. Dengan menggunakan fasilatas yang dimiliki oleh Google Maps kita dapat menemukan posisi atau letak suatu tempat atau daerah dengan luasan area sehingga dalam pencarian lokasi tersebut tidak terlalu meluas.

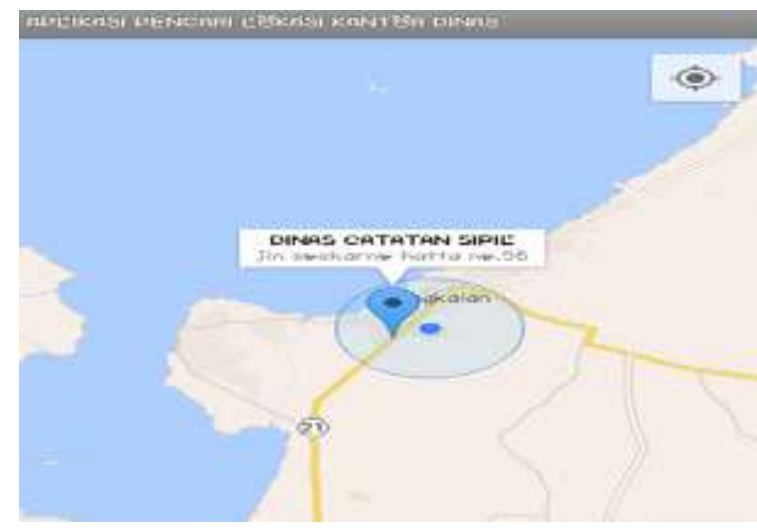

\section{Gambar 5. Tampilan Peta Dan marker Dinas}

Selain dapat melihat lokasi maka pada aplikasi ini dilengkapi juga dengan pencarian rute terdekat, seperti pada Gambar 6. Dari gambar tersebut kita diberika informasi tentang jarak sebenarnya dari posisi kita yang sekarang sampai ke tempat tujuan. Dari informasi tersebut kita juga diberikan informasi tentang jalan yang terpendek menuju tempat dinas yang akan dituju. Apabila anda sudah memahami rute maka anda tidak perlu untuk melihat rute yang terdekat. Bagi anda pendatang baru disarankan untuk memilih lihat peta, sehingga para pengguna akan mengenal lokasi wilayah kantor dinas di Bangkalan beserta informasi tentang dinas tersebut.

Selain itu kita juga diberikan beberapa pilihan alternative dalam mencapai ke lokasi tujuan yaitu dengan mengendarai mobil pribadi, naik angkutan umum atau bahkan berjalan kaki. Dari aplikasi tersebut akan muncul jarak tempuh dan waktu dibutuhkan samai ke tempat tujuan. 


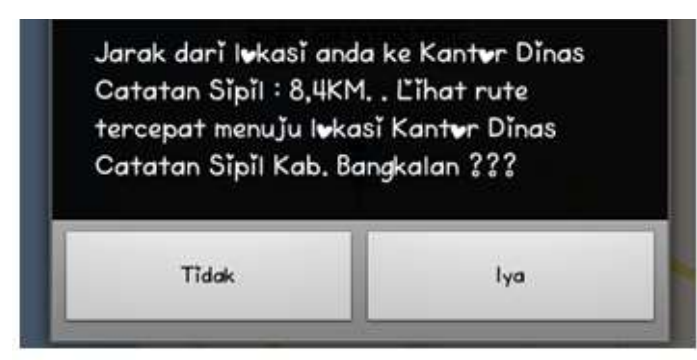

(a)

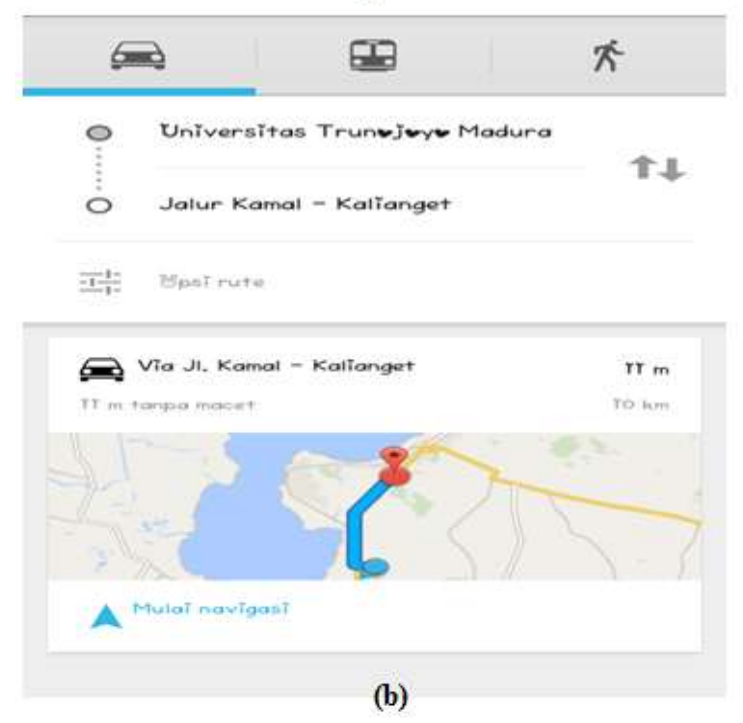

Gambar 6. (a) Form Pilihan Lihat Rute, (b) Tampilan Rute Pada Peta

\section{KESIMPULAN}

Berdasarkan hasil ujicoba yang telah dilakukan pada penelitian ini menunjukkan bahwa mampu merancang dan membangun aplikasi mobile yang berbasis android untuk pengguna dan aplikasi database server untuk administrator pada pengolahan data. Aplikasi ini dapat melakukan pencarian lokasi kantor dinas menggunakan smartphone android

sehingga mempermudah dalam proses pencarian lokasi, informasi layanan dan rute di tiap kantor dinas wilayah Madura khususnya Bangkalan baik Dinas Capil, Dinas Kesehatan, Dinas Pendidikan, Dinas Koperasi, dan Dinas Pertanian di Kabupaten Bangkalan dengan sistem layanan berbasis lokasi (LBS) berbasis android.

\section{PUSTAKA}

Arfiani, Ika. 2012. "Sistem Informasi Geografis Untuk Pemetaan Dan Pencarian Rumah Sakit Di Kota Yogyakarta", Jurnal Informatika, Vol 6, No.2, Juli, hal.1-10.

Eddy Prahasta. 2009. "SIG Konsep-Konsep Dasar Perspektif Geodensi dan Geomatika", Informatika, Bandung. Oktober. Halaman 20-25.

Pengertian dinas kabupaten atau kota. http://www.dinaswikipedia.org, diakses pada 01 agustus 2014.

Ria Awaliya, 2013, "Sistem Informasi Geografis Pemetaan Lokasi Tempat Kursus EF (English First) Di Wilayah Kota Jakarta Dengan Menggunakan ArcView", Jakarta: Univ. Gunadarma, Jurusan Sistem Informasi, Fakultas Ilmu Komputer dan Teknologi Informasi. pp. 1-10.

Sanjaya, I, dkk. 2012. "Pembuatan Aplikasi Sistem Informasi Geografis Sumber Daya Air Dan Perairan", Jurnal algoritma sekolah tinggi teknologi garut, ISSN: 2302-7339 Vol.09, No.10, Hal.7-13.

Sari Rahmi Nursuci. 2011. "Sistem Informasi Geografi Tempat Ibadah Di Kota Bogor Berbasis Web Dengan Menggunakan Quantum GIS”. Jakarta: Universitas Gunadarma, Jurusan Sistem Informasi, Fakultas Ilmu Komputer dan Teknologi Informasi. pp. 1-10.

Tawang, N., 2012. "Aplikasi Layanan Pencari Lokasi Kuliner Terdekat Di Yogyakarta Berbasis Android". Yogyakarta:STMIK AMIKOM 